\title{
Corn agronomic traits and recovery of nitrogen from fertilizer during crop season and off-season
}

\author{
Luis Felipe Garcia Fuentes(1), Luiz Carlos Ferreira de Souza ${ }^{(1)}$, Ademar Pereira Serra(2), \\ Jerusa Rech ${ }^{(1)}$ and Antonio Carlos Tadeu Vitorino(1)
}

\begin{abstract}
(1)Universidade Federal da Grande Dourados, Faculdade de Agronomia, Rodovia Dourados-Itahum, Km 12, Cidade Universitária, Caixa Postal 533, CEP 79804-970 Dourados, MS, Brazil. E-mail: lufegafu@hotmail.com, luizsouza@ufgd.edu.br, jerusarech@hotmail.com, antoniovitorino@hotmail.com ${ }^{(2)}$ Embrapa Gado de Corte, Avenida Rádio Maia, no 830, Zona Rural, CEP 79106-550 Campo Grande, MS, Brazil. E-mail: ademar.serra@embrapa.br
\end{abstract}

Abstract - The objective of this work was to evaluate corn agronomic traits in a cultivation subjected to different $\mathrm{N}$ rates, during the fall-winter (off-season) and spring-summer crop seasons, and $\mathrm{N}$ recovery from fertilizer. The experiment was set up in a randomized complete block design with four replicates, in a $5 \times 2$ factorial arrangement, with the following treatments: five $\mathrm{N}$ topdressing rates $-0,30,60,90$, and $120 \mathrm{~kg} \mathrm{ha}^{-1}$ -, using urea as source; and two crop seasons, fall-winter and spring-summer. The following variables were determined: plant height, height of the first ear insertion, number of grains per ear, diameter and length of ear, 1,000-grain weight, $\mathrm{N}$ concentration in the leaves and grains, grain-protein concentration, grain yield, $\mathrm{N}$ recovery from fertilizer, and soil-N supply. Nitrogen rates in the fertilizer in the fall-winter season had no effect on grain yield, although corn agronomic traits showed a greater reliance on fertilizer- $\mathrm{N}$ rates in that season than in the spring-summer, which is a season associated to a greater capacity of soil-N supply to plants. The quantification of soil-N supply enabled knowing the nutrient dynamics during the fall-winter and the spring-summer seasons, which may be useful to guide $\mathrm{N}$ fertilization of corn.

Index terms: Zea mays, $\mathrm{N}$-fertilizer management, plant nutrition, soil fertility, soil-N supply.

\section{Características agronômicas do milho e recuperação de nitrogênio do fertilizante durante a safra e a safrinha}

\begin{abstract}
Resumo - O objetivo deste trabalho foi avaliar características agronômicas do milho em um cultivo submetido a diferentes doses de $\mathrm{N}$, nas safras de outono-inverno (safrinha) e primavera-verão, e a recuperação do $\mathrm{N}$ do fertilizante. $\mathrm{O}$ experimento foi disposto em blocos ao acaso, com quatro repetições, em arranjo fatorial $5 \times 2$, com os seguintes tratamentos: cinco doses de $\mathrm{N}$ em cobertura - 0, 30, 60, 90 e $120 \mathrm{~kg} \mathrm{ha}^{-1}$-, com uso de ureia como fonte; e duas estações de cultivo, outono-inverno e primavera-verão. As seguintes variáveis foram determinadas: altura de planta, altura da inserção da primeira espiga, número de grãos por espiga, diâmetro e comprimento da espiga, massa de 1.000 grãos, concentração de $\mathrm{N}$ nas folhas e nos grãos, concentração de proteína nos grãos, produtividade de grãos, recuperação de $\mathrm{N}$ do fertilizante e suprimento de $\mathrm{N}$ pelo solo. As taxas de $\mathrm{N}$ do fertilizante na estação outono-inverno não influenciaram a produtividade de grãos, embora as características agronômicas do milho tenham apresentado maior dependência do $\mathrm{N}$ do fertilizante naquela estação do que na primavera-verão, que é uma estação associada a uma maior capacidade do solo de fornecer $\mathrm{N}$ para as plantas. A quantificação do suprimento de $\mathrm{N}$ pelo solo permitiu saber a dinâmica do nutriente durante a safrinha e a safra de primavera-verão, o que pode ser útil para guiar a fertilização nitrogenada do milho.
\end{abstract}

Termos para indexação: Zea mays, manejo da adubação nitrogenada, nutrição de plantas, fertilidade do solo, suprimento de $\mathrm{N}$ pelo solo.

\section{Introduction}

Nitrogen use efficiency in cereals is quite low - 33\% on average (Raun \& Jonhson, 1999). As reported by Bruulsema et al. (2009), the "4R nutrient stewardship" (right rate, right source, right place, and right time) is necessary to make decisions regarding the $\mathrm{N}$-fertilization aiming at social, economic, and environmental benefits.

Urea is the most common $\mathrm{N}$ source applied in crops around the world, because of its high-N content and cost effectiveness (Pan et al., 2016). However, N
Pesq. agropec. bras., Brasília, v.53, n.10, p.1158-1166, Oct. 2018 DOI: 10.1590/S0100-204X2018001000009
This is an open-access article distributed under the Creative Commons Attribution 4.0 International License 
losses from urea through $\mathrm{NH}_{3}$ volatilization is a major problem, decreasing the $\mathrm{N}$ use efficiency from this source even in acid soils, since urease activity increases $\mathrm{pH}$ in the vicinity of fertilizer particles (Hawkesford et al., 2012). This fact, added to other $\mathrm{N}$ losses that may occur, can result in little $\mathrm{N}$ recovery from fertilizers, if the nutrient losses are not minimized.

Water deficits also decrease fertilizer-N recovery by corn (Fosu-Mensah \& Mensah, 2016), and this can be an important constraint for grain yield, especially in the off-season crops. In Brazil, most corn cultivations are performed during the off-season (fall-winter), and $\mathrm{N}$ fertilizers are commonly avoided in this season due to their expensive cost and low efficiency. In order to improve the cost effectiveness of $\mathrm{N}$ fertilizer, corn agronomic performance under different $\mathrm{N}$ rates during the off-season should be more studied to improve $\mathrm{N}$ fertilizer recommendations. In this sense, the amount of $\mathrm{N}$ exported through harvest, the remaining $\mathrm{N}$ in the soil, and the expected grain yield should all be considered to improve the recovery of $\mathrm{N}$ from the fertilizer and avoid soil-N depletion over time.

The objective of this work was to evaluate the effects of $\mathrm{N}$ fertilizer rates on corn agronomic traits and on recovery of $\mathrm{N}$ from the fertilizer, during the fall-winter and spring-summer crop seasons.

\section{Materials and Methods}

This research was carried out in a Latossolo Vermelho (Rhodic Hapludox), according to Santos et al. (2013), with a clayey texture and clay mineralogy constituted mainly by $\mathrm{Al} / \mathrm{Fe}$ oxy-hydroxides. The experimental site is located in the municipality of Dourados, in the state of Mato Grosso do Sul, Brazil ( $22^{\circ} 13^{\prime} 16^{\prime \prime S}, 54^{\circ} 48^{\prime} 2^{\prime \prime} \mathrm{W}$, at $430 \mathrm{~m}$ altitude). Soil samples were collected (0-0.20-m depth) in January 2015, before the establishment of the experiment, to define the fertilizer rates and determine the soil chemical and physical properties (Claessen, 1997): $5.54 \mathrm{pH}\left(\mathrm{CaCl}_{2}\right)$; $28.38 \mathrm{~g} \mathrm{dm}^{-3}$ soil organic matter; $12.8 \mathrm{mg} \mathrm{dm}^{-3} \mathrm{P} ; 1.5$ $\mathrm{cmol}_{\mathrm{c}} \mathrm{dm}^{-3} \mathrm{~K}^{+} ; 5.34 \mathrm{cmol}_{\mathrm{c}} \mathrm{dm}^{-3} \mathrm{Ca}^{2+} ; 2.01 \mathrm{cmol}_{\mathrm{c}} \mathrm{dm}^{-3}$ $\mathrm{Mg}^{2+} ; 6.5 \mathrm{cmol}_{\mathrm{c}} \mathrm{dm}^{-3} \mathrm{H}+\mathrm{Al} ; 0 \mathrm{cmol}_{\mathrm{c}} \mathrm{dm}^{-3} \mathrm{Al}^{3+} ; 8.8 \mathrm{cmol}_{\mathrm{c}}$ $\mathrm{dm}^{-3}$ sum of base; $15.3 \mathrm{cmol}_{\mathrm{c}} \mathrm{dm}^{-3}$ cations exchange capacity; $57.7 \%$ base saturation; and 531, 249, and 220 $\mathrm{g} \mathrm{kg}^{-1}$ clay, silt, and sand, respectively.

Data on rainfall and on maximum and minimum temperatures, in the experimental site, are shown in
Figure 1. In the fall-winter season, corn was cultivated in the field from March to July 2015; and, in the springsummer season, from October to February (2015/2016). According to the classification of Köppen-Geiger (Koeppen, 1948), the region has a tropical climate (Cwa), with rainy summer and dry winter.

The experiment design was set up in a randomized complete block design, with four replicates, and the treatments were placed in a $5 \times 2$ factorial arrangement consisting of five $\mathrm{N}$ top-dressing rates $-0,30,60,90$, and $120 \mathrm{~kg} \mathrm{ha}^{-1}-$, using urea as $\mathrm{N}$ source, and two crop seasons - fall-winter and spring-summer. $\mathrm{N}$-fertilizer rates above $120 \mathrm{~kg} \mathrm{ha}^{-1}$ were not tested because of their high costs and usually low economic returns. The $\mathrm{N}$ rates were applied at the V5 development stage (plant with five leaves). In order to increase the $\mathrm{N}$ use efficiency and minimize the $\mathrm{NH}_{3}-\mathrm{N}$ volatilization, $\mathrm{N}$-fertilizer rates were incorporated down to $0.05 \mathrm{~m}$ depth, $0.10 \mathrm{~m}$ apart from the plant rows. The experimental units had $30 \mathrm{~m}^{2}$, and mechanized operations were performed with a 112-HP wheel tractor.

Before the experiment implementation, the area was cultivated in a no-till system, with a rotation of soybean, in spring-summer, and corn in the fall-winter season, since October 1, 2005. The corn cultivar BR 473 was sown on February $11^{\text {th }}, 2015$, and on October $7^{\text {th }}, 2015$, in soil managed in conventional tillage. The harvesting occurred on June $17^{\text {th }}$ (fall-winter season) and on February $6^{\text {th }}, 2016$ (spring-summer season). Planting was performed with 6 seeds $\mathrm{m}^{-1}$, and the plant rows were spaced at $1.00 \mathrm{~m}$ from each other, resulting in 60,000 plants per hectare. The fertilizer was applied at $8 \mathrm{~cm}$ soil depth in the seeding rows, at $16 \mathrm{~kg} \mathrm{~N} \mathrm{ha}^{-1}$, $50 \mathrm{~kg} \mathrm{~K}_{2} \mathrm{O} \mathrm{ha}^{-1}, 50 \mathrm{~kg} \mathrm{P}_{2} \mathrm{O}_{5} \mathrm{ha}^{-1}, 0.9 \mathrm{~kg} \mathrm{Zn} \mathrm{ha}^{-1}$, and $0.9 \mathrm{~kg} \mathrm{~B} \mathrm{ha}^{-1}$.

Weed control was done with $0.7 \mathrm{~L} \mathrm{ha}^{-1}$ nicosulfuron and $3.0 \mathrm{~L} \mathrm{ha}^{-1}$ atrazine which were sprayed on weed in the beginning of their vegetative stage (two leaves completely opened), at corn vegetative growth (V2),

The harvest occurred on June $17^{\text {th }}, 2015$, and on February $6^{\text {th }}, 2016$. The following variables were determined at harvest: plant height, height of the first ear insertion, number of grains per ear, ear diameter and ear length, stem diameter, 1,000-grain weight, leaf-N concentration, grain-N concentration, grain-protein concentration, recovery of $\mathrm{N}$ from the fertilizer (RNF), soil-N supply, $\mathrm{N}$ exported in the harvesting, and corn grain yield. Plant height was measured from the soil

Pesq. agropec. bras., Brasília, v.53, n.10, p.1158-1166, Oct. 2018 DOI: 10.1590/S0100-204X2018001000009 
surface to the basis of the flag leaf, in the beginning of the reproductive stage (R1), while the height of the first ear insertion was measured from the soil surface to the primary ear node. Leaf-N and grain-N concentrations were determined following the method described by Malavolta et al. (1997), and grain-crude-protein concentration was obtained by the multiplication of grain-N concentrations by the factor 6.25 .

Soil-N supply (\%) was determined dividing the grain- $\mathrm{N}$ concentrations in the unfertilized plots $\left(\mathrm{GNC}_{\mathrm{u}}, \mathrm{g} \mathrm{kg}^{-1}\right)$ by the ones in the fertilized plots $\left(\mathrm{GNC}_{\mathrm{f}}\right.$, $\mathrm{g} \mathrm{kg}^{-1}$ ). The recovery of $\mathrm{N}$ from the fertilizer (RNF) was calculated following the methodology reported by Raun \& Johnson (1999), according to the equation: $\mathrm{RNF}(\%)=100\left(\mathrm{GNC}_{\mathrm{f}}-\mathrm{GNC}_{\mathrm{u}}\right) / \mathrm{NFA}$; where NFA is the $\mathrm{N}$-fertilizer applied rate $\left(\mathrm{kg} \mathrm{ha}^{-1}\right)$.

The variables evaluated in the experiment were subjected to the analysis of variance and, when significant, their data were fitted to regression equations, with the aid of SPSS software (SPSS Inc., 2007). Principal components analysis (PCA) was calculated to explain the structure of the variance and covariance in the original variables. The variance contained in each principal component (PC) is expressed by eigenvalues of the standard matrix, in which the higher eigenvalues are associated with

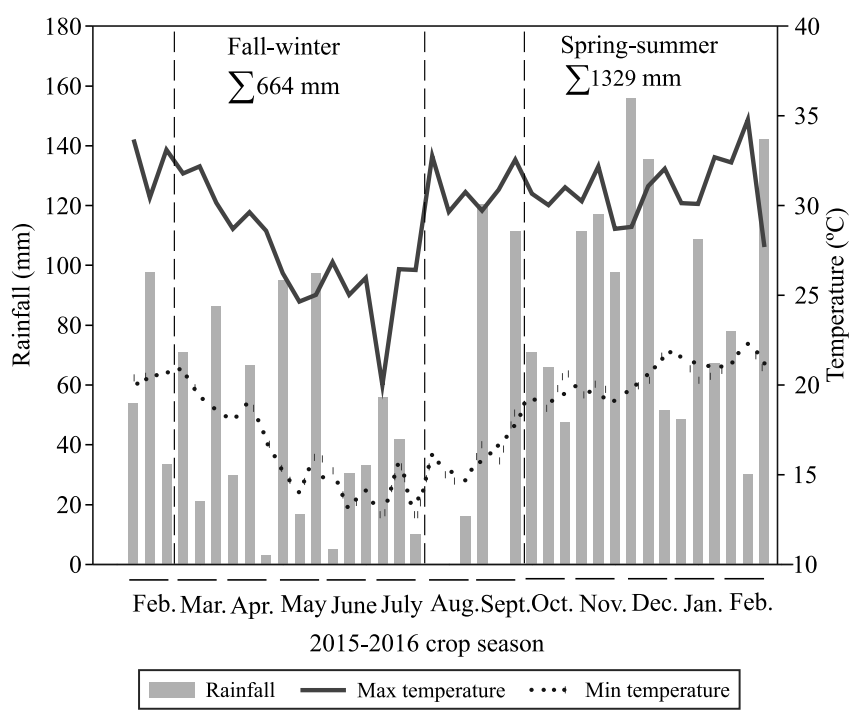

Figure 1. Decennial rainfall, maximum and minimum air temperatures, during the fall-winter (March to July 2015) and spring-summer (October to February 2015/2016) seasons. Data obtained from the meteorological station at Universidade Federal da Grande Dourados, Dourados, MS, Brazil.
PC-1; the second higher eigenvalues, with PC-2; until the minor eigenvalue, which is associated with the last PC. Therefore, the first principal component (PC-1) explains the most variance of the original variables. The loading significance was determined according to Collins \& Ovalles (1988), and PC loadings, or correlations between original variables and the first two PCs, had to be greater than a selection criterion (SC) for acceptation. The selection criterion proposed by Collins \& Ovalles (1988) was defined as $\mathrm{SC}=0.50 /(\mathrm{PC} \text { eigenvalue })^{0.5}$.

\section{Results and Discussion}

Plant height was higher in the spring-summer than in the fall-winter season, and increased with the application of $\mathrm{N}$-fertilizer. The number of grains per ear was also affected by the $\mathrm{N}$ rates, but the crop seasons had no effect on it. However, there was effect on the stem diameter and ear length, and the springsummer crop season resulted in higher stem diameter, ear length, and 1,000-grain weight (Figure 2).

The increase of plant growth in the spring-summer season was associated with better weather conditions of temperature and rainfall (Figure 1). The fall-winter season was relatively dry $(664 \mathrm{~mm})$, while the springsummer was rainy $(1,329 \mathrm{~mm})$. Furthermore, worse agronomic traits were observed in the fall-winter, mostly due to the lower temperature in this period, which reduces plant growth and, consequently, the photosynthesis efficiency (Dohleman \& Long, 2009; Bergamaschi et al., 2010; Chen et al., 2013).

Leaf-N, grain-N and grain-protein concentrations increased with the $\mathrm{N}$ application rates (Figure 3), and they were all greater in the spring-summer than in the fall-winter season. Irrespective of the yield potential of the corn cultivar, decreased $\mathrm{N}$ supply results in proportional reduction of photosynthesis, PEPcarboxylase, and $\mathrm{RuBisCO}$ activities (Uribelarrea et al., 2009), which consequently decreases $\mathrm{CO}_{2}$ fixing capacity and grain protein concentration.

Soil-N supply reduced linearly with $\mathrm{N}$-fertilizer rates, in both crop seasons (Figure 4). The evaluation of soil-N supply enabled a greater understanding of the $\mathrm{N}$ dynamics in the evaluated seasons, which might be useful to reduce the corn reliance on $\mathrm{N}$-fertilizer rates. Most $\mathrm{N}$ recommendations for this crop do not take soil-N supply into consideration, which could possibly reduce the amount of $\mathrm{N}$-fertilizer required by the crops. 

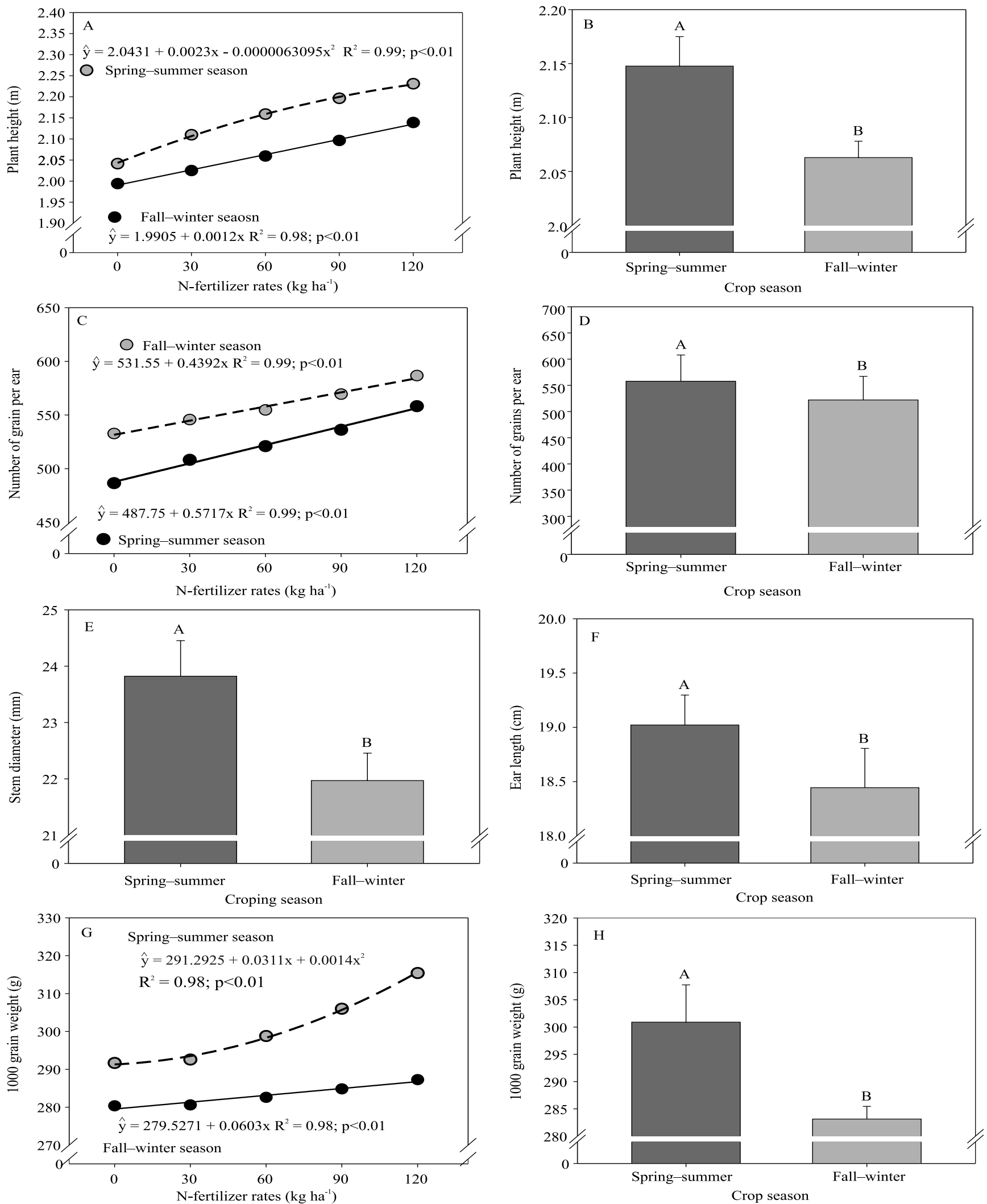

Figure 2. Agronomic traits of corn cultivated under different N-fertilizer rates and crop seasons (spring-summer and fall-winter). Means followed by equal letters do not differ, by the t-test, at 5\% probability. Vertical bars correspond to the standard error. 
The proportion of $\mathrm{N}$ uptake from the soil and accumulated in the grain decreased $23.72 \%$ with the rate of $120 \mathrm{~kg} \mathrm{~N} \mathrm{ha}^{-1}$, in comparison to $\mathrm{N}_{0}$. Most of the $\mathrm{N}$ uptake by corn came from the soil natural supply, and less than $36.90 \%$ came from the fertilizer. Even at the high-N rate of $120 \mathrm{~kg} \mathrm{ha}^{-1}$, the minimum proportion of soil-N in the grain was $75 \%$. This greater importance of soil-N supply for corn mineral nutrition agrees with those reported by Raun \& Johnson (1999).

The recovery of $\mathrm{N}$ from the fertilizer was lower in the spring-summer than that of the fall-winter
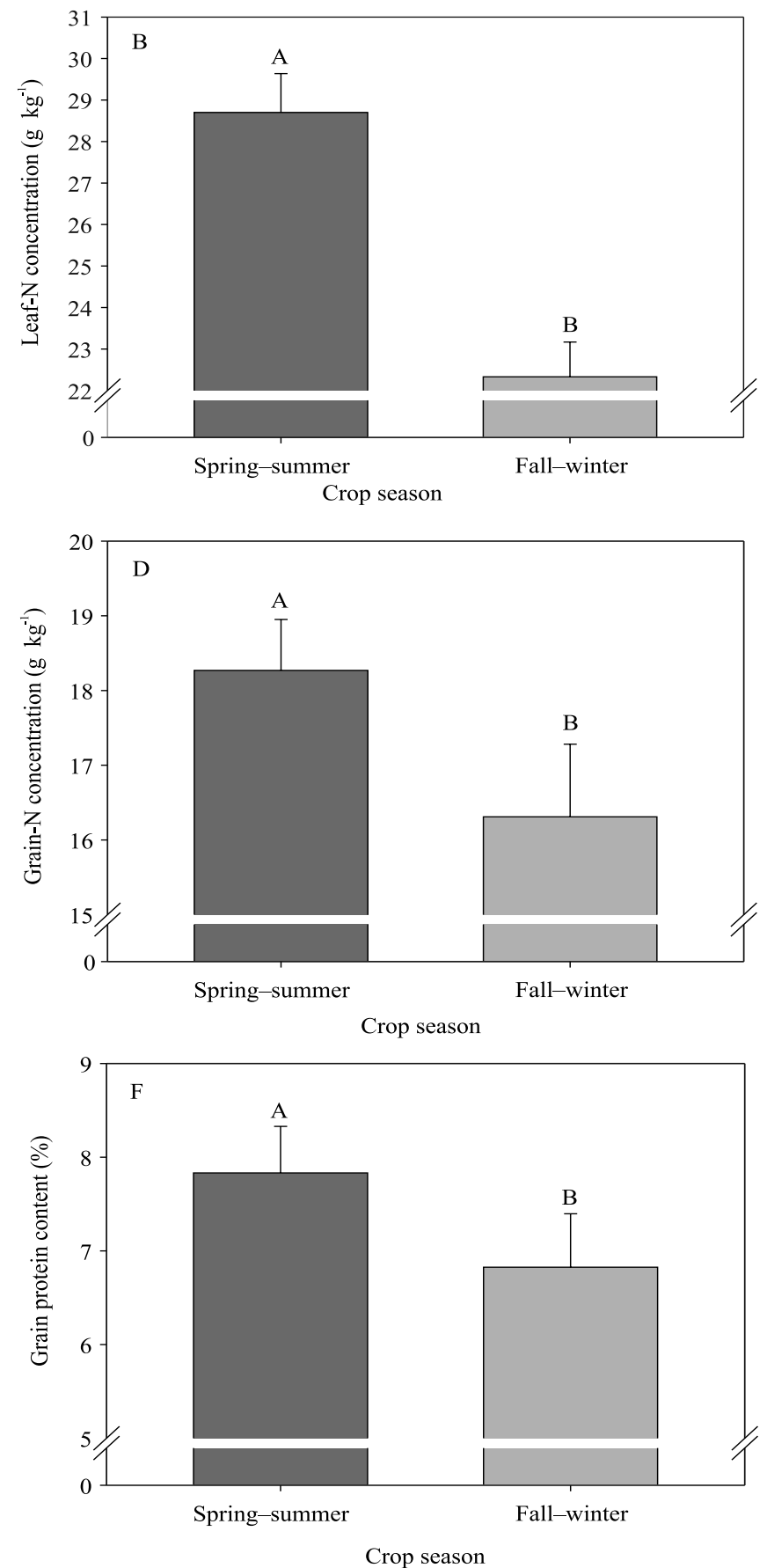

Figure 3. Nitrogen concentrations in leaves and grains, and grain-protein content in corn cultivation subjected to different $\mathrm{N}$-fertilizer rates and crop seasons (spring-summer and fall-winter). Means followed by equal letters do not differ, by the t-test, at $5 \%$ probability. Vertical bars correspond to standard error. 
(Table 1). In both crop seasons, the recovery of $\mathrm{N}$ from the fertilizer ranged from 25.99 to $36.90 \%$, which is within the range of $20-50 \%$ generally reported for this variable (Francis et al., 1993). Corn planted in the fall-
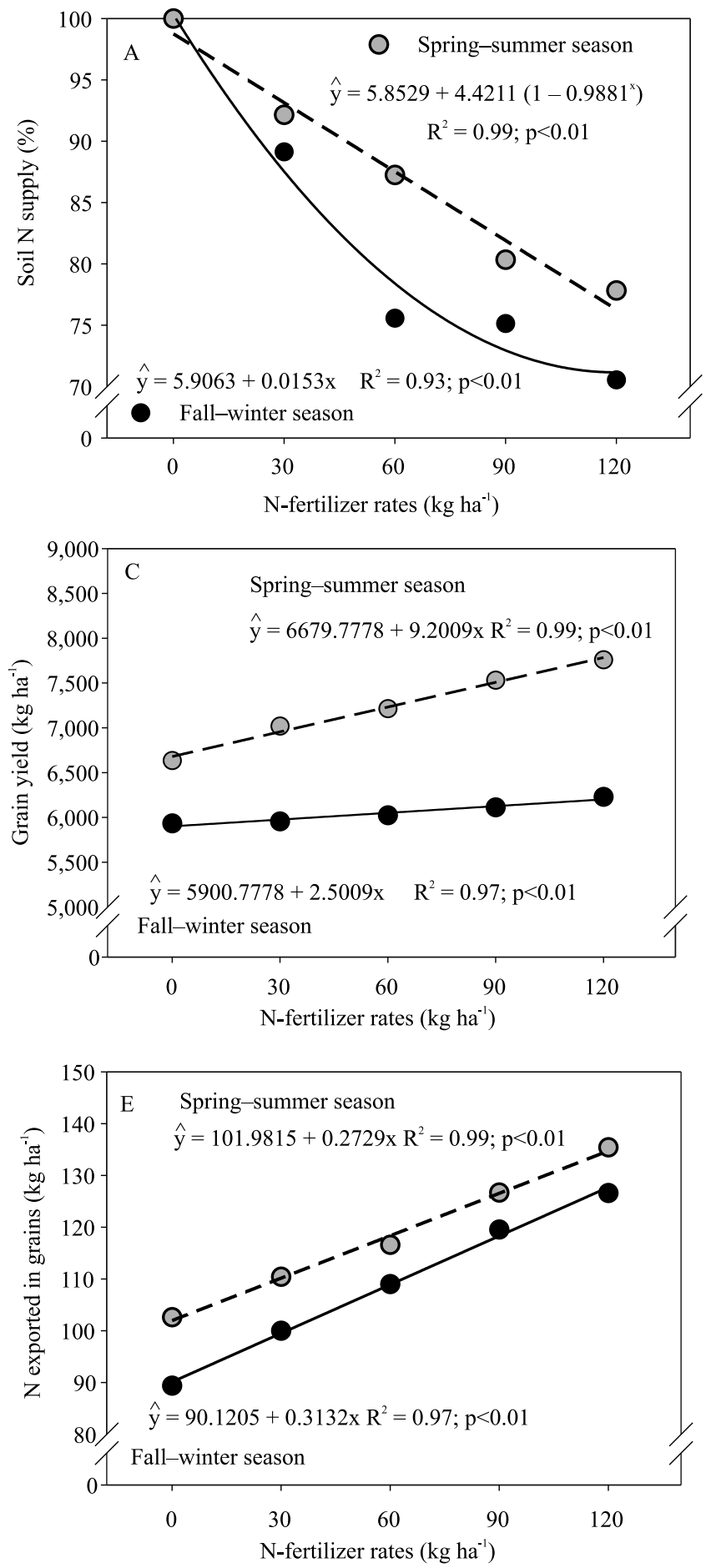

winter season showed a greater reliance on $\mathrm{N}$-fertilizer than that planted in the spring-summer. The amount of $\mathrm{N}$ supplied by the soil to the grains, with the $\mathrm{N}$ rate of $0 \mathrm{~kg} \mathrm{ha}^{-1}$, was $89.29 \mathrm{~kg} \mathrm{~N} \mathrm{ha}^{-1}$. Conversely, in
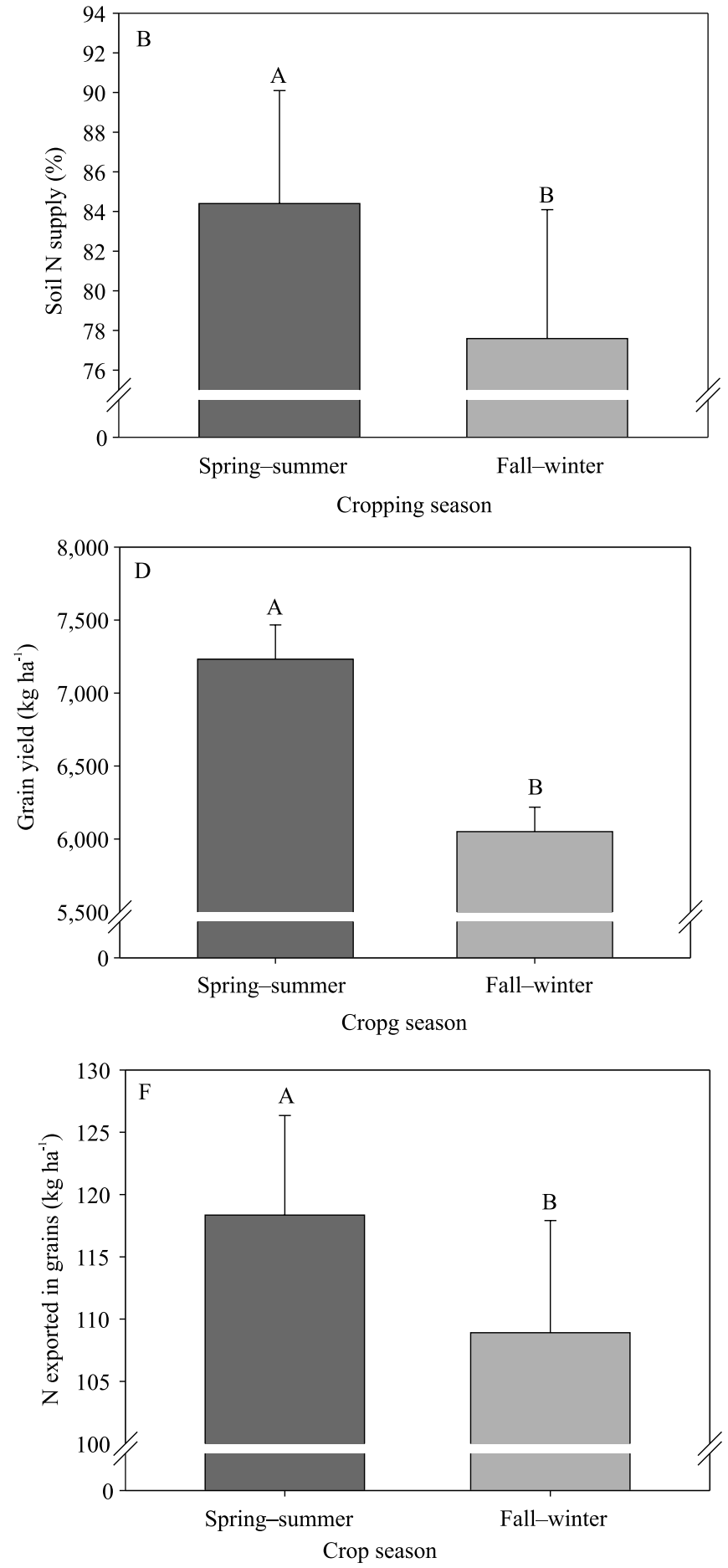

Figure 4. Soil-N supply, 1,000 grain weight, and grain yield of a corn cultivation subjected to different $\mathrm{N}$-fertilizer rates and crop seasons (spring-summer and fall-winter). Means followed by equal letters do not differ, by the t-test, at 5\% probability. Vertical bars correspond to standard error. 
the spring-summer season, it was $102.18 \mathrm{~kg} \mathrm{~N} \mathrm{ha}^{-1}$. Higher mineralization rates occur in the springsummer season, which increases the $\mathrm{N}$ supply by the soil, and decreases the recovery of $\mathrm{N}$ from the fertilizer. Moreover, the higher recovery of $\mathrm{N}$ from the fertilizer, in the fall-winter season, can be associated with lower losses of $\mathrm{NH}_{3}-\mathrm{N}$ and $\mathrm{NO}_{3}-\mathrm{N}$ by leaching, since the higher-soil moisture in the spring-summer (Figure 1) can increase them due to the greater water translocation through the soil profile.

Ideal conditions for the soil organic matter mineralization (SOM) are temperatures in the soil ranging from 40 to $60^{\circ} \mathrm{C}$, soil-water capacity of 50$70 \%, \mathrm{pH} 6-7$, and a good soil aeration (Potrich et al., 2014). These conditions can not be achieved in the fall-winter season in tropical climate because of the dry winter (Figure 1).

The application of $120 \mathrm{~kg} \mathrm{~N}^{-1}$ resulted in a $5 \%$ increase of grain yield in the fall-winter season (Figure 4), whereas, in the spring-summer season, it grain yield increased $17 \%$, in comparison the to absence of N-fertilizer. Grain yield in the springsummer was $19.5 \%$ higher than in the fall-winter, which may be associated to better weather conditions (rainfall and temperature) in the spring-summer season. Nevertheless, grain yield average in the fall-winter season was greater than the Brazilian grain yield average for the off-season $\left(5,713 \mathrm{~kg} \mathrm{ha}^{-1}\right)$ (Acompanhamento..., 2016).

Corn small response to $\mathrm{N}$-fertilizer rates in the fall-winter season justifies the cultivation of this crop without any expense with $\mathrm{N}$-fertilizer, which is usually done in Brazil. However, the continue cultivation without $\mathrm{N}$ fertilizations may deplete SOM over time and, consequently, the soil-N supply (Davis et al., 2003). Nonetheless, the absence of $\mathrm{N}$-fertilizer rates in the fall-winter season can be considered a sustainable

Table 1. Recovery of $\mathrm{N}$ from fertilizer in the fall-winter and spring-summer seasons of corn cultivation ${ }^{(1)}$.

\begin{tabular}{lccc}
\hline $\begin{array}{l}\text { N-fertilizer } \\
\text { rates }\left(\mathrm{kg} \mathrm{ha}^{-1}\right)\end{array}$ & \multicolumn{2}{c}{ Recovery of N from fertilizer (\%) } & $\begin{array}{c}\text { Difference of } \\
\text { seasons (\%) }\end{array}$ \\
\cline { 2 - 3 } 0 & Fall-winter & Spring-summer & - \\
30 & - & - & 7.96 \\
60 & $35.88 \mathrm{Aa}$ & $27.92 \mathrm{Ba}$ & 14.68 \\
90 & $37.95 \mathrm{Aa}$ & $23.27 \mathrm{Ba}$ & 6.84 \\
120 & $33.91 \mathrm{Aa}$ & $27.06 \mathrm{Ba}$ & 2.98 \\
\hline
\end{tabular}

${ }^{(1)}$ Means followed by equal letters, lowercase in the columns and uppercase in the lines, do not differ, by Tukey's test, at $5 \%$ probability. alternative, especially if crop rotation is applied with Leguminosae plants, which can improve the soil-N supply due to $\mathrm{N}$ fixation in the spring-summer (Sainju et al., 2016).

The exportation of $\mathrm{N}$ to grains increased $32.11 \%$ with the increase of $\mathrm{N}$ application rates from 0 to 120 $\mathrm{kg} \mathrm{ha}^{-1}$, in the spring-summer season. In the fall-winter season, this increase was of $41.70 \%$. Exportation of soil-N to grains ranged from 90.12 to $101.98 \mathrm{~kg} \mathrm{~N} \mathrm{ha}^{-1}$, confirming that soil-N supply is the greatest $\mathrm{N}$ source for corn. In all occasions, the amount of $\mathrm{N}$ exported to grains was greater than the applied rate of $\mathrm{N}$-fertilizer .

In both crop seasons, most variance in the evaluated variables could be attributed to two principal components (Table 2). Most PC loadings were significant, according to the selection criterion defined by Collins \& Ovalles (1988), except for stem diameter. The first two PC explained 57.56 and 53.82\% of the variance for the fall-winter and spring-summer seasons, respectively.

First PC in the fall-winter season was positively correlated to plant height (PH), ear length (EL), ear diameter (ED), number of grain per ear (NGE), corn grain yield (GY), 1,000-grain weight $(1,000 \mathrm{GW})$, leaf-N concentration (LNC), grain-N concentration (GNC), grain-protein concentration (GPC), and

Table 2. Correlations between variables and the first two principal components (PC) in the fall-winter and spring-summer seasons of a corn cultivation ${ }^{(1)}$.

\begin{tabular}{lccccc}
\hline Variable & \multicolumn{2}{c}{ Fall-winter } & & \multicolumn{2}{l}{ Spring-summer } \\
\cline { 2 - 3 } \cline { 5 - 6 } & PC-1 & PC-2 & & PC-1 & PC-2 \\
\hline Plant height & $\underline{0.74}$ & -0.30 & & $\underline{0.84}$ & 0.10 \\
Height of the first ear insertion & $\underline{-0.64}$ & $\underline{-0.55}$ & & $\underline{0.81}$ & 0.19 \\
Stem diameter & -0.02 & -0.14 & & -0.15 & 0.26 \\
Ear length & $\underline{0.59}$ & -0.07 & & $\underline{0.32}$ & $\underline{0.41}$ \\
Ear diameter & $\underline{0.42}$ & $\underline{0.72}$ & & $\underline{0.56}$ & -0.14 \\
Number of grains per ear & $\underline{0.56}$ & 0.30 & & $\underline{0.79}$ & 0.19 \\
Grain yield & $\underline{0.29}$ & -0.70 & & $\underline{0.66}$ & $\underline{0.54}$ \\
1,000-grain weight & $\underline{0.60}$ & -0.17 & & $\underline{0.54}$ & $\underline{0.45}$ \\
Leaf-N concentration & $\underline{0.86}$ & -0.06 & & $\underline{0.88}$ & 0.07 \\
Grain-N concentration & $\underline{0.91}$ & -0.10 & & $\underline{0.49}$ & $\underline{-0.58}$ \\
Grain-protein concentration & $\underline{0.90}$ & 0.02 & & $\underline{0.62}$ & $\underline{-0.53}$ \\
Soil-N supply & $\underline{-0.88}$ & 0.09 & & $\underline{-0.53}$ & $\underline{0.61}$ \\
Recovery of N from fertilizer & $\underline{0.73}$ & -0.07 & & $\underline{0.54}$ & -0.21 \\
Eigenvalues & 5.916 & 1.567 & & 5.130 & 1.867 \\
Explained variance (\%) & 45.51 & 14.05 & & 39.46 & 14.36 \\
Accumulated variance (\%) & 45.51 & 57.56 & & 39.46 & 53.82 \\
Selection criterion (SC) & 0.21 & 0.40 & & 0.22 & 0.37 \\
\hline (1)Underlined values had dominant & PC loadings, according to the signifi- \\
cance level defined by Collins \& & Ovalles & $(1988)$. & &
\end{tabular}


recovery of $\mathrm{N}$ from the fertilizer (RNF). And it was negatively correlated to the height of first ear insertion (HFEI) and soil-N supply (SNS) (Figure 5 A). The
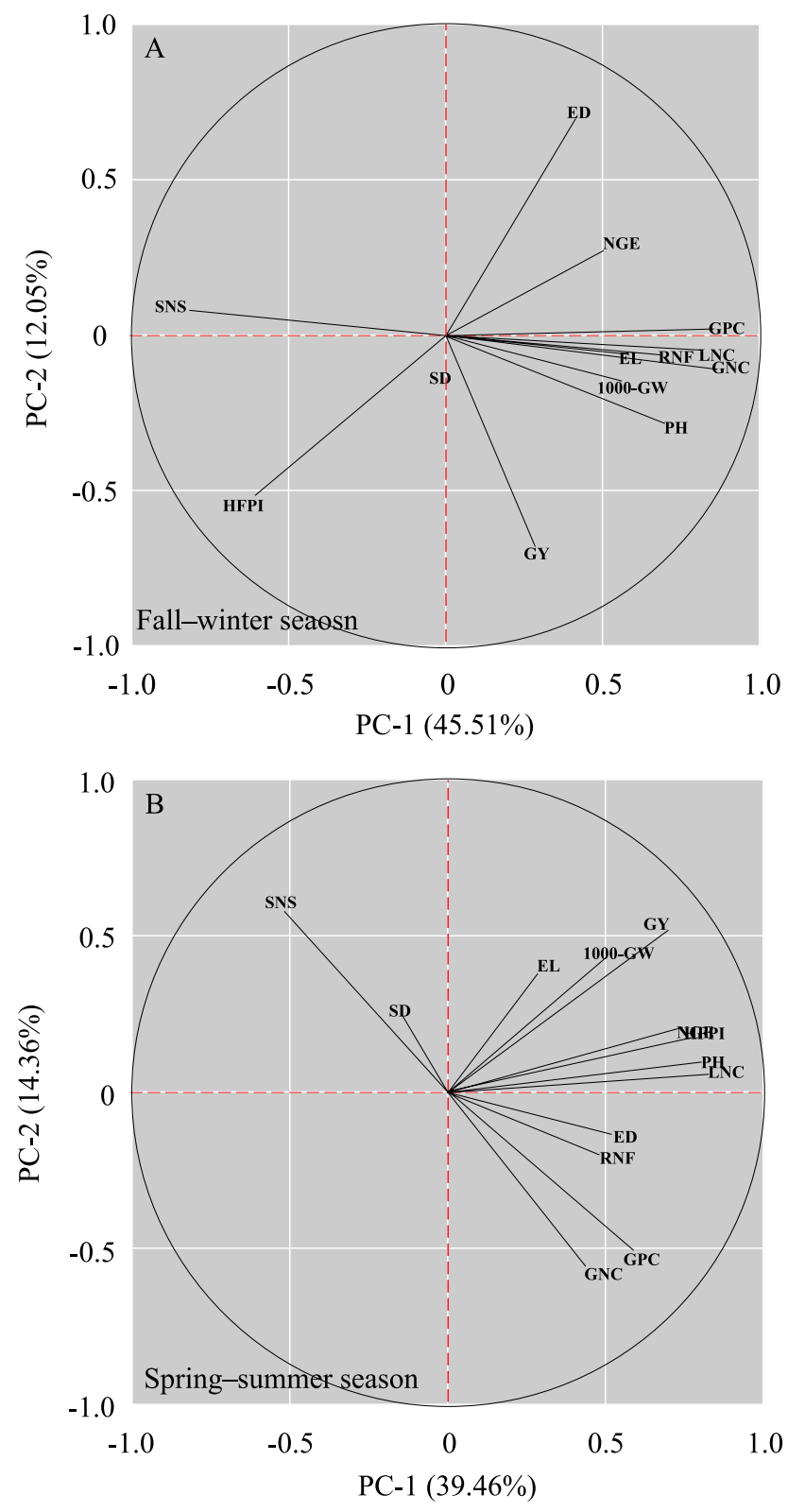

Figure 5. Scatted diagrams for the first two principal components (PC) of 13 variables evaluated in two crop seasons (fall-winter and spring-summer) of a corn cultivation. SNS, soil-N supply; HFEI, height of the first ear insertion; SD, stem diameter; GY, grain yield; $\mathrm{PH}$, plant height; 1,000-GW, weight of 1,000 grains; EL, ear length; RNF, recovery of $\mathrm{N}$ from the fertilizer; $\mathrm{LNC}$, leaf-N concentration; GNC, grain-N concentration; $\mathrm{CPC}$, crude protein content; NGE, number of grains per ear; and ED, ear diameter. first PC in the spring-summer season was positively correlated to PH, HFEI, EL, ED, NGE, GY, 1,000GW, LNC, GNC, GP and RNF, and negatively correlated to SNS.

In the comparisons between the crop seasons, PC-1 in fall-winter and spring-summer showed similarity of variation structures among the variables, with just one exception for HFEI. However, PC-2 did not show any agreement among the variability, and was in the fall-winter season positively correlated with ED, and negatively correlated with HFEI and GY. In the spring-summer season, PC-2 showed a positive correlation with EL, GY, 1,000GW, and SNS.

Ambiguous relationships among variables are expected due to the less than $100 \%$ variability of the PC. Nevertheless, some important patterns were observed in the first two principal components, in both crop seasons. In the fall-winter season, PC-1 was directly related to most of the variables, and inversely related to SNS. PCA analyses confirmed the greater reliance of corn cultivated on the recovery of $\mathrm{N}$ from the fertilizer in the fall-winter season. These analyses also confirmed that soil-N supply was lower in the fall-winter, and that the higher-soil-N supply in the spring-summer season decreased the crop reliance on the $\mathrm{N}$-fertilizer rates.

\section{Conclusions}

1. Top-dressing with $\mathrm{N}$-fertilizers can be avoided in the fall-winter season due to the absence of a profitable response of corn grain yield.

2. The amount of $\mathrm{N}$ exported to corn grains is higher than the $\mathrm{N}$-fertilizer rates applied, regardless of the season, since soil-N supply is the major source of the nutrient for corn.

3. In the fall-winter season, the agronomic traits of corn rely more on $\mathrm{N}$-fertilizer rates than in the springsummer season.

4. The knowledge on soil-N supply in the different crop seasons should be used to guide $\mathrm{N}$-fertilizer rates for corn cultivation.

\section{Acknowledgments}

To Conselho Nacional de Desenvolvimento Científico e Tecnológico (CNPq) and to Fundação de Apoio ao Desenvolvimento do Ensino, Ciência e Tecnologia do Estado de Mato Grosso do Sul (Fundect/

Pesq. agropec. bras., Brasília, v.53, n.10, p.1158-1166, Oct. 2018 DOI: $10.1590 / \mathrm{S} 0100-204 X 2018001000009$ 
MS), for financial support; and to Consejo Nacional de Ciencia y Tecnologia (Conacyt), for the scholarship to the first author.

\section{References}

ACOMPANHAMENTO DA SAFRA BRASILEIRA [DE] GRÃOS: safra 2015/16: quarto levantamento, v.3, n.4, jan. 2016.

BERGAMASCHI, H.; DALMAGO, G.A.; BERGONCI, J.I.; KRÜGER, C.A.M.B.; HECKLER, B.M.M.; COMIRAN, F. Intercepted solar radiation by maize crops subjected to different tillage systems and water availability levels. Pesquisa Agropecuária Brasileira, v.45, p.1331-1341, 2010. DOI: 10.1590/ S0100-204X2010001200001.

BRUULSEMA, T.; LEMUNYON, J.; HERZ, B. Know your fertilizer rights. Crops and Soils, v.42, p.13-18, 2009.

CHEN, C.; BAETHGEN, W.E.; ROBERTSON, A. Contributions of individual variation in temperature, solar radiation and precipitation to crop yield in the North China Plain, 1961-2003. Climatic Change, v.116, p.767-788, 2013. DOI: 10.1007/s10584012-0509-2.

CLAESSEN, M.E.C. (Org.). Manual de métodos de análise de solo. 2.ed. rev. e atual. Rio de Janeiro: Embrapa-CNPS, 1997.212p.

COLLINS, M.E.; OVALLES, F.A. Variability of northwest Florida soils by principal component analysis. Soil Science Society of America Journal, v.52, p.430-1435, 1988. DOI: 10.2136/sssaj1988.03615995005200050042x.

DAVIS, R.L., PATTON, J.J.; TEAL, R.K.; TANG, Y.; HUMPHREYS, M.T.; MOSALI, J.; GIRMA, K.; LAWLES, J.W.; MOGES, S.M.; MALAPATI, A.; SI, J.; ZHANG, H.; DENG, S.; JOHNSON, G.V.; MULLEN, R.W.; RAUN, W.R. Nitrogen balance in the Magruder plots following 109 years in continuous winter wheat. Journal of Plant Nutrition, v.26, p.1561-1580, 2003. DOI: 10.1081/PLN-120022364.

DOHLEMAN, F.G.; LONG, S.P. More productive than maize in the midwest: How does Miscanthus do it? Plant Physiology, v.150, p.2104-2115, 2009. DOI: 10.1104/pp.109.139162.

FOSU-MENSAH, B.Y.; MENSAH, M. The effect of phosphorus and nitrogen fertilizers on grain yield, nutrient uptake and use efficiency of two maize (Zea mays L.) varieties under rain fed condition on Haplic Lixisol in the forest-savannah transition zone of Ghana. Environmental Systems Research, v.5, art.22, 2016. DOI: $10.1186 / \mathrm{s} 40068-016-0073-2$.

HAWKESFORD, M.; HORST, W.; KICHEY, T.; LAMBERS, H.; SCHJOERRING, J.; MOLLER, I.S; WHITE, P. Functions of macronutrients. In: MARSCHNER, P. (Ed.). Marschner's mineral nutrition of higher plants. $3^{\text {rd }}$ ed. Amsterdam: Elsevier, 2012. p.135-151. DOI: 10.1016/B978-0-12-384905-2.00006-6.

KOEPPEN, W. Climatología: con un estudio de los climas de la tierra. México: Fondo de Cultura Económica, 1948. 478p.

MALAVOLTA, E.; VITTI, G.C.; OLIVEIRA, S.A. de. Princípios, métodos e técnicas de avaliação do estado nutricional. In: MALAVOLTA, E.; VITTI, G.C.; OLIVEIRA, S.A. de. (Ed.). Avaliação do estado nutricional de plantas: princípios e aplicações. 2.ed. Piracicaba: Potafos, 1997. p.115-230.

PAN, B.; LAM, S.K.; MOSIER, A.; LUO, Y.; CHEN, D. Ammonia volatilization from synthetic fertilizers and its mitigation strategies: A global synthesis. Agriculture, Ecosystems and Environment, v.232, p.283-289, 2016. DOI: 10.1016/j.agee.2016.08.019.

POTRICH, D.C.; MARCHETTI, M. E.; POTRICH, D.C.; ENSINAS, S.C.; SERRA, A.P.; SILVA, E.F. da; SOUZA, N.H. de. Decomposição de resíduos culturais de cana-de-açúcar submetidos a diferentes doses de nitrogênio. Semina: Ciências Agrárias, v.35, p.1751-1760, 2014. DOI: 10.5433/1679-0359.2014v35n4p1751.

RAUN, W.R.; JOHNSON, G.V. Improving nitrogen use efficiency for cereal production. Agronomy Journal, v.91, p.357-363, 1999. DOI: 10.2134/agronj1999.00021962009100030001x.

SAINJU, U.M.; LENSSEN, A.W.; ALLEN, B.L.; STEVENS, W.B.; JABRO, J.D. Nitrogen balance in response to dryland crop rotations and cultural practices. Agriculture, Ecosystems and Environment, v.233, p.25-32, 2016. DOI: 10.1016/j. agee.2016.08.023.

SANTOS, H.G. dos; JACOMINE, P.K.T.; ANJOS, L.H.C. dos; OLIVEIRA, V.A. de; LUMBRERAS, J.F.; COELHO, M.R.; ALMEIDA, J.A. de; CUNHA, T.J.F.; OLIVEIRA, J.B. de. Sistema brasileiro de classificação de solos. 3.ed. rev. e ampl. Brasília: Embrapa, 2013. 353p.

SPSS Inc. SPSS for Windows, Version 16.0. Chicago, 2007.

URIBELARREA, M.; CRAFTS-BRANDNER, S.J.; BELOW, F.E. Physiological $\mathrm{N}$ response of field-grown maize hybrids (Zea mays L.) with divergent yield potential and grain protein concentration. Plant Soil, v.316, p.151-160, 2009. DOI: 10.1007/ s11104-008-9767-1.

Received on May 11, 2017 and accepted on December 21, 2017

Pesq. agropec. bras., Brasília, v.53, n.10, p.1158-1166, Oct. 2018

DOI: 10.1590/S0100-204X2018001000009 